\title{
Borderland City: Kharkiv
}

\author{
Volodymyr Kravchenko \\ University of Alberta
}

\section{Translated from Ukrainian by Marta Olynyk ${ }^{1}$}

\begin{abstract}
The article attempts to identify Kharkiv's place on the mental map of the Russian Empire and the Soviet Union, and traces the changing image of the city in Ukrainian and Russian narratives up to the end of the twentieth century. The author explores the role of Kharkiv in the symbolic reconfiguration of the Ukrainian-Russian borderland and describes how the interplay of imperial, national, and local contexts left an imprint on the city's symbolic space.
\end{abstract}

Keywords: Kharkiv, city, region, image, Ukraine, Russia, borderland.

$\mathbf{K}$

harkiv is the second largest city in Ukraine after Kyiv. Once (1920-34), it even managed to replace the latter in its role of the capital of Ukraine.

Having lost its metropolitan status, Kharkiv is now an important transport hub and a modern megapolis that boasts a greater number of universities and colleges than any other city in Ukraine. Strategically located on the route from Moscow to the Crimea, Kharkiv became the most influential component of the historical Ukrainian-Russian borderland, which has been a subject of symbolic and political reconfiguration and reinterpretation since the middle of the seventeenth century. These aspects of the city's history have attracted the attention of numerous scholars (Bagalei and Miller; Iarmysh et al.; Masliichuk).

Recent methodological "turns" in the humanities and social sciences shifted the focus of urban studies from the social reality to the city as an imagined social construct and to urban mythology and identity (Arnold; Emden et al.; Low; Nilsson; Westwood and Williams). This intellectual vogue is making its way to Ukrainian urban studies as well (Amar; Bilenky; Czaplicka, Lviv; Czaplicka et al.; Hamm; Herlihy; Hrytsenko; Richardson;

\footnotetext{
1 [First published under the title "Stolytsia dlia Ukrainy" ("A Capital City for Ukraine") in Volodymyr Kravchenko, Ukraina, imperiia, Rosiia: Vybrani statti z modernoi istorii ta istoriohrafii, Krytyka, 2011, pp. 45-86. This article is a revised version of the text, mainly in terms of bibliography and structure. It was translated in 2014 for my unpublished collection of articles in English, and its current version was further copy-edited by Marcia Craig, EWJUS-V.K.].
} 
Schlögel; Sylvester). Against this background, Kharkiv seems to be somewhat underrated.

Different aspects of the symbolic dimension of Kharkiv's past and present are reflected in texts written primarily by Ukrainian writers and philologists (Dolengo; Shevel'ov; Zaharchenko). For most of these writers, the city's identity has been presumed to be inherently Ukrainian. However, "Ukraine" obtained its exclusive national meaning relatively recently, in the twentieth century. Before that, "Ukraine" was used in combination with other determinants that oscillated between having either territorial or national meanings. Nowadays, when Ukrainian nation-state building is still in-progress, the idea of "Ukrainianness" is subjected to redefinition. It remains to be seen to what extent and in what form Kharkiv has been inscribed in the modern Ukrainian national narrative.

In this historical overview I will try to trace the evolution of the images of Kharkiv city in various texts created primarily but not exclusively by different authors in the nineteenth and twentieth centuries. These authors represent different genres and have different views of Kharkiv's identity in ever-changing and overlapping regional, imperial, and national contexts. Kharkiv's urban narrative was not merely a reflection of the national context; it was capable of collecting its own symbolic potential, which impacted both imperial and national narratives of identity from local or regional perspectives. Therefore, I dwell on the formation of and changes in Kharkiv's symbolic landscape and mythology.

Kharkiv was a capital of the historical region known as Sloboda Ukraine. It bordered several other historical regions: "South Russia," Malorossiia (literally "Little Russia"), Novorossiia (literally "New Russia"), and the Donbas (Donets Basin). Each region played an important role in the permanent shaping and reshaping of the Ukrainian-Russian borderland with its porous boundaries and elusive or hybrid identities. Regional discourses demonstrate surprising persistence in a changeable socio-political context during the last two hundred years. Their role increased at the time of rapid transformations (Augusteijn and Storm; Berger and Miller; Núñez; Paasi; Sklokin). That is why an overview of Kharkiv's various images starts with the regional aspects of its history.

\section{THE REGION}

Kharkiv emerged in the mid-seventeenth century in the transition zone between the forest-steppe and the steppe. The rivers and the steppe roads leading to them influenced the south-north communication routes in this land. The famous Muravs'kyi Route crossed the steppe and linked the Muscovite Tsardom with the Crimean Khanate. At the dawn of Kharkiv's 
history there were no natural barriers marking the boundaries of the region, which was usually referred to as a "Ukraine" a.k.a. "borderland" or "a land on the edge." Its configuration was a product of an everchanging geopolitical context.

Kharkiv arose on the contested territory claimed simultaneously by Muscovy, the Polish-Lithuanian Rzeczpospolita, and the Crimean Khanate (Breyfogle et al.; LeDonne). It was a bone of contention among the military polities of the Cossack Hetmanate, the Zaporozhian Sich, the Don Cossack Host, and the Tatar hordes that were nominally subordinate to Bakhchysarai (Bahçesaray), the capital of the Crimean Khanate. This territory began to be actively settled, under the Russian government's control, by refugees escaping from Ukrainian lands that were engulfed by the Cossack war led by Bohdan Khmel'nyts'kyi in the mid-seventeenth century. That is when and how the former Steppe "Ukraine" started its social transformation from a military frontier into the "Sloboda Ukraine" border region, a kind of a militarized "free economic zone" divided into five Cossack regiments under Belgorod voyevoda's supervision.

The Sloboda Ukraine became a magnet for people who were in conflict with the government in their homelands. These were not only Ukrainian colonists-peasants and Cossacks-but also Russian religious dissidents, the Old Believers, who formed the nucleus of subsequent powerful dynasties of local merchants. Later, they were joined by colonists from the Balkans who filled the ranks of the local military elite and service stratum. Soldiers and officers who were captured by Russian troops during the many wars that the Russian Empire was waging at the time against Turkey, the Rzeczpospolita, and France were sent to Sloboda Ukraine during the eighteenth and the early part of the nineteenth centuries. They were followed by immigrants from the west (predominantly Polish and German lands) and the east (mostly from Caucasian regions).

Kharkiv's urban space took form at a slow pace. For a long time, the city remained sparsely populated. The city's population during the first 150 years barely exceeded 10,000. Kharkiv lacked even the external attributes of an urban milieu, remaining a fortified free settlement undistinguished in any way from other settlements on the steppe frontier. The founders of Kharkiv- "rabble and country bumpkins," according to a local Russian governor-continued their accustomed way of life in the new location, establishing outlying farms, engaging in rural trades, distilling beverages, and practicing commerce (Bagalei and Miller 1: 21).

Narrow and crooked streets, thatch-covered wood houses, quantities of mud that were unheard of even in the provinces, a terrible microclimate, lack of sanitation, and high mortality rate were some of the features of Kharkiv that left a profoundly negative impression on visitors. In the early nineteenth century, the Russian explorer Pavel Sumarokov was amazed that Kharkiv in 
no way resembled Russian cities (Bagalei and Miller 2: 965-66), while the Polish historian Ludwik Janowski noted that Kharkiv was significantly behind its neighbouring Russian cities, Belgorod, Kursk, and Voronezh (Janowski 45-46).

Kharkiv's significance to the Russian Empire was initially based mainly on military and political considerations. Of all the Cossack regimental outposts in the Steppe, Kharkiv had the most strategically advantageous location, as it was situated on the southern route of Russian expansion. Thus, Kharkiv became the hub of large-scale wholesale trade and the headquarters of the commander-in-chief of the Russian army. From the moment of its founding, Kharkiv began to develop wholesale markets, which were very soon counted among the largest in the empire. Following the establishment of the Kharkiv Orthodox Collegium (1726) and the founding of an eparchy (1799), Kharkiv gained primacy over Belgorod, which had been considered the main centre of Russian control over the steppe borderland since the midseventeenth century.

Kharkiv's cultural geography was defined by different sources. On the one hand, it was a spiritual territory of the Russian Orthodox Church, which regarded Kharkiv as the outpost of Orthodoxy on the steppe cultural border. The new settlers carried out the symbolic transformation of the steppe space, not only with the aid of purely Slavic toponyms but also through its sacralization: the building of Orthodox churches and monasteries and the establishment of cults devoted to local saints and wonder-working icons like the Ozeriany or Okhtyrka icons of the Mother of God. The differences in the church rites brought by the Ukrainian colonists were gradually erased over the course of the changes that were taking place in the Russian Orthodox Church throughout the eighteenth century.

On the other hand, from a secular perspective, Kharkiv may be considered part of the Ukrainian-Polish cultural borderland. The social model of the Polish szlachta (gentry) became an important means of legitimizing the noble status of the colonists in the new, Russian-dominated environment. The first literary monument to place Kharkiv on the cultural map of Europe in the early eighteenth century was a panegyric "Bogaty wirydarz" ("The Rich Orchard"), written in the Polish language by the Ukrainian author from Chernihiv, Jan Ornowski (Ukr., Ivan Ornovs'kyi), and published in Kyiv in 1705. It was dedicated to the Donets'-Zakharzhevs'kyi Cossack family who were considered to be Kharkiv's founding fathers. Calendars, the first publications to be issued by the Orthodox church printing houses in Kharkiv in the late eighteenth century, were translated from the Polish language. During the first half of the nineteenth century, Kharkiv University maintained close contact with Vilnius University and the Kremenets Lyceum; a number of Polish scholars taught in Kharkiv, and Polish students occasionally comprised up to one-third of the student body 
of the local university.

In 1765, Kharkiv became an administrative centre of the Sloboda Ukraine gubernia. ${ }^{2}$ However, the real significance of Kharkiv extended far beyond its boundaries. The Kharkiv military governor's sphere of authority encompassed the Belgorod, Voronezh, Kazan, Saratov, and Astrakhan gubernias, as well as the Don Cossack Host, that is, the whole steppe borderland where the privileged areas ("slobody") were located. The Kharkiv Orthodox Collegium trained priests for the entire Russian and Ukrainian steppe frontier. At the beginning of the nineteenth century, the newly established Kharkiv School District encompassed, in addition to the adjacent Russian lands, the entire left bank of the Dnipro River together with the Crimea and the Caucasus. Kharkiv became one of the main economic, administrative and cultural centres of a large region. The question arises: what region...?

\section{"UKRAINE"}

In Russian historical sources, the lands that were set aside for the colonists were most often called "okraina" or "ukraina," meaning "borderland." Everything located on that territory was called "Ukrainian": from the new settlements to the Russian military which operated under the official name of Ukrainian Army. Symbolically, Kharkiv's "Ukrainian" identity was bolstered after the city was transformed into the centre of the Sloboda Ukraine gubernia, and its new status was reflected in the words of contemporary intellectuals like Hryhorii Skovoroda, ${ }^{3}$ Hryhorii Kalynovs'kyi, or the titles of the first local journals Ukrainskii vestnik (The Ukrainian Courier) and Ukrainskii zhurnal (The Ukrainian Journal). Kharkiv residents were widely identified as "Ukrainians" regardless of their ethnic affiliation.

The "Ukrainian" localization of Kharkiv and region was supported by the notion that they constituted a cultural borderland as seen from the north, i.e., from both capitals of the Russian Empire. For example, in the St. Petersburg satirical journal Zhivopisets (Painter), "Ukrainian" geographic space was marked in 1772 by mentioning the names of the cities Poltava, Kharkiv, and Hovtva, and an imaginary local newspaper was titled Ukrainskie vedomosti (Ukrainian News). The "mores" of the cultural borderland were portrayed ironically in correspondence supposedly cited from that newspaper by Zhivopisets: hunting with hounds, a banquet, and a

\footnotetext{
${ }^{2}$ In 1780 it was renamed Kharkiv Vice-Regency (Russ., "namestnichestvo”). In 1796, the former official name was restored, and was changed in 1834 to Kharkiv gubernia. 3 The philosopher called Sloboda Ukraine/the Kharkiv region "Ukraine," and his fatherland (the former Hetmanate) "Little Russia."
} 
mentally unsound landowner searching for someone to whom to sell his conscience.

By the mid-nineteenth century, Kharkiv had become firmly identifiedunofficially-as the "centre point" of "Ukraine." For example, it was referred to as the "capital of Ukraine" in the notes of the German traveller Johann Georg Kohl, who passed through the city in 1838 (Bagalei and Miller 2: 968). The well-known Russian literary critic Vissarion Belinskii repeated Kohl's reference almost word for word. In the early 1840s, Belinskii, too, had recourse to the "capital" metaphor to express his impression of the city: "Kharkiv, in its populousness and beauty as compared to other gubernia towns, is in a way the capital of Ukraine, and hence the capital of Ukrainian literature, of Ukrainian prose and, in particular, of Ukrainian verse" (Belinskii 89).

Contrary to the examples above, Vasilii Karazin (Ukr., Vasyl' Karazyn), the distinguished enlightener and civic activist who became a founding father of Kharkiv University, dreamed of the day when his "small fatherland" would finally lose its "borderland" status, get rid of its "Ukrainian" name, and becomes similar to the central Russian gubernias. His dream appeared to come true in 1834, when the name of the Sloboda Ukraine gubernia was changed to Kharkiv gubernia, but he could hardly foresee that, having lost its local "Ukrainian" "registration," Kharkiv drew closer to Poltava and Chernihiv, the administrative capitals of Little Russia. However, at that time, both "Ukraine" and "Little Russia" started to lose their respective regional identities and began to acquire new, ethnic meanings.

\section{“LiTTLE RUSSIA"}

Kharkiv arose in a borderland territory, separated from Little Russia by administrative and legal borders. The enlightenment reforms of Catherine II and Alexander I in the late eighteenth and early nineteenth centuries did not entirely supplant the traditions of regional estate particularism. Kharkiv basically retained a regional character and the administrative boundary that continued to divide Little Russia from the Sloboda region in the nineteenth century.

In the Little Russian historical narrative, the Sloboda Ukraine region was depicted as a borderland, settled by "upstarts" from the common people brazen enough to make totally unfounded claims to membership in the Cossack gentry. Generally speaking, the Little Russian historical narrative retained negative stereotypes with regard to Sloboda Ukraine that had grown out of the experience of political struggle in the mid- and late seventeenth century, when the paths of the two Ukrainian Cossack regions sometimes diverged considerably. It is telling that for the author of Istoriia 
Rusov (History of the People of Rus'), the name "Ukraine" was associated with the borderland, that is, with the lower social status of peripheral territory in relation to the centre, which for him remained Little-Russia-Rus' (see Istoriia Rusov 3-4).

Quite naturally, historians of the Sloboda region, who came from the local Cossack elite, hastened to refute their Little Russian opponents by presenting proofs of their "noble" origins. The historical narrative written by Illia Kvitka in the second half of the eighteenth century was based on the feats of local "little hetmans" in loyal and irreproachable service to the Russian throne and on the unbroken sequence of favours and privileges that the Slobodians had received from Russian monarchs $(4-9,11,19)$. Naturally, that loyalty shone all the more brightly against the sombre record of the "traitors"-the Little Russian hetmans Ivan Vyhovs'kyi, Ivan Briukhovets'kyi, and Petro Doroshenko. It is noteworthy that Illia Kvitka based the historical identity of the Sloboda region on its political opposition to Little Russia. The former represented the coming era of modern intellectualism while the latter was stuck in premodern social elitist traditions.

\section{"SOUTH RUSSIA"}

During the reign of Catherine II, the political map of eastern Europe changed profoundly. Russian imperial borders with the Polish-Lithuanian Commonwealth, the Ottoman Empire, and the Crimean Khanate changed six times between 1772 and 1795 as a result of wars and annexations. That number increases if one considers the Ukrainian borders with the Cossack Hetmanate, the Zaporozhian Sich, and the Sloboda Ukraine region, which were constantly redrawn in the course of administrative and political reforms and the modernization of the empire's steppe borderland. The reorientation of imperial policy from north to south indicated the direction of the Russian Empire's further expansion toward the Black Sea littoral and the Caucasus (Zorin; Eliseeva).

With the rise of new cities and administrative territories in the southern Russian Empire, the contours of a new region known as South Russia gradually became apparent. The region retained its significance as a military base for the further expansion of the Russian Empire. As a supplement to that role, it took on new cultural and civilizational dimensions. The new region was meant to become a symbol of modernization in the backward but dynamically developing Russian Empire. The southern Russian cities were planned and built according to ancient models as understood in Russia at the time, and some of their names referred to the ancient Greek's legacy.

"South Russia" was meant to become a melting pot of the historical 
border regions, including the "old" Cossack regions of Little Russia and Sloboda Ukraine. That is why its "southern" geographical identification was usually accompanied with the "new" markers clearly reflected in the local toponymy. However, "New Russia," while receiving the status of a gubernia and even a general governorate, did not encompass the whole expanse of "South Russia" and remained only part of it (Bagalei and Miller 1: 291). As a result, "South Russia” became something of a meta-regional shell covering a poorly structured space that included the remains of various regional identities. The boundaries and centre of the new region remained undefined. Subsequently, several claimants of regional supremacy emerged in Southern Russia, including the cities of Katerynoslav, Odesa, Kyiv, and Kharkiv.

Obviously, the plan concerning Katerynoslav was drafted with the intention to move the imperial capital there during the reign of Catherine II (Iavornitskii 54). However, the only feature left of this plan is the name of the city and its square-grid layout. Odesa, one of the most dynamic and most cosmopolitan cities in the empire (Herlihy), could have become the best candidate for the regional capital of "South Russia," but ultimately limited itself to being the centre of the "New Russia." Finally, Kyiv, which also found itself in the imagined space of "South Russia," was regarded as too old and traditional to be considered a centre of modernization.

Kharkiv's place in the southern sphere of the Russian Empire was identified around the turn of the eighteenth century. As "South Russia" turned into a model space of enlightened modernization, Sloboda Ukraine became part of it. The process of drawing the Sloboda region into the "South Russian" symbolic space was started, probably, by Ivan Pereverzev, the author of Topograficheskoe opisanie Khar'kovskogo namestnichestva (Topographic Description of the Kharkiv Viceregency), in the late 1780s, and was continued by Karazin. It was conducted later by the local intellectuals within the framework of civilizing or modernizing discourse. Kharkiv's southern identification was already well established in the first half of the nineteenth century. Baron von Haxthausen called Kharkiv one of the most important, most beautiful, and most promising cities of southern Russia, and said that Kharkiv could be compared to Odesa in the way that Moscow was compared to St. Petersburg (Haxthausen-Abbenburg 397).

Kharkiv's "southern" symbolic and geographic identification was intensified sometime in the mid-nineteenth century when Kyiv, as a result of the policy aimed at Russianizing the Polish Right-Bank "kresy" (borderlands), acquired the status of capital city of "South-Western Russia," and Odesa was situated more firmly within the borders of "New Russia." Out of Kharkiv's closest competitors in the region, only Katerynoslav remained, but the city at that time laid claim to the role of unofficial capital of the new industrial and raw material region known as the Donetsk/Kryvyi Rih Basin, or simply Donbas. 
Kharkiv's southern geographic self-identification was consolidated throughout the nineteenth century. To newcomers arriving from Russia, Kharkiv looked like a southern city thanks to its climate. Kharkiv's public space was replete with "southern" markers of self-identification. These included the newspaper Iuzhnyi krai (The Southern Land), with the largestcirculation in the city, a multitude of civic organizations and institutions, and especially the railway station of the Southern Railway, which had replaced the ancient Muravs'kyi Route in the second half of the nineteenth century.

\section{REINTERPRETATION OF THE REGION: THE CASE OF KHARKIV UNIVERSITY}

The interplay between the border regions of South/New Russia, Little Russia, Sloboda Ukraine, and even the Polish-dominated Right Bank of Dnipro ("kresy") found vivid expression in the establishment of Kharkiv University, initiated by Karazin and supported by the imperial authorities. Karazin actively promoted an idea of establishing Kharkiv as "the focus of enlightenment of southern Russia" (Kravchenko 112). In a letter to the governor general of Little Russia, Prince Aleksandr Kurakin, Karazin weighed the chances of various cities-Poltava, Kyiv, Kharkiv, and Chernihiv - with regard to the founding of a university. He stressed that Kyiv lay in the sphere of Polish influence, while Poltava maintained "some kind of unconquerable alienation from the Great Russian inhabitants" and was too far removed from the Russian towns of Orel, Kursk, and Voronezh (Kravchenko 106). The Sloboda region and therefore Kharkiv city, in Karazin's opinion, had none of those blemishes. It is worth mentioning in this regard that Karazin's university project found favour in two South Russian gubernias, those of Katerynoslav and Kherson, whose gentry donated substantial amounts of money in support of Kharkiv University. Thus, Sloboda Ukraine and Little Russia became the main competitors for hosting a university and the educational network that would be built around it.

At the meetings of the governmental secondary education committee in 1802-03, only two cities on Ukrainian ethnic territory were initially considered for the role of university centres-Kyiv, which was regarded as the historical, cultural, and religious "focus" of Little Russia, and Kharkiv, the new administrative and cultural centre of the Sloboda Ukraine region. Furthermore, the leading Western specialists invited by the Russian government, which included the former instructor of the successor to the Russian throne, the Swiss Frédéric-César de La Harpe, and a well-known educational reformer from the Austrian Empire, the Serb Teodor JankovićMirijevski, gave preference to Kyiv, placing it on the same level as Moscow, Dorpat, Vilnius, St. Petersburg, and Kazan (Kravchenko 105).

Kharkiv yielded in every respect to Kyiv, the "second Jerusalem," the 
cradle of Orthodoxy in Rus', and the historical centre of Little Russia. No wonder that Karazin's project for the founding of Kharkiv University did not garner sympathy in the neighbouring Poltava and Chernihiv gubernias of Little Russia, whose gentry continued to nourish hopes of fulfilling their own projects of establishing universities in the former Hetmanate. Highly placed Little Russians, the imperial ministers Petro Zavadovs'kyi and Viktor Kochubei, sought openly or covertly to undermine Karazin's plans. Disappointed by such sabotage, Karazin went so far as to assert that in future he would be guided exclusively by the interests of his own "small homeland," the Sloboda Ukraine region, and not Little Russia, which was allegedly mocking his efforts (Kravchenko 106).

Illia Tymkovs'kyi, a contemporary of Karazin who agreed with him about the university project, and later became one of the first professors at Kharkiv University, tried to convince the Little Russian elite that there was no point in petitioning for a university in Poltava or Chernihiv, given that Kharkiv University was being "built near and in a land inhabited by its relatives." Such arguments did not help: in the eyes of the regional elites; ethnic commonality took second place to estate privileges. The story of the university project was repeated several years later, when the Sloboda gentry, developing a project for the founding of an institute for noble maidens in Kharkiv, went so far as to propose that it be called a Little Russian institute and to invite the gentry of the neighbouring Little Russian gubernias to take part in establishing it. But this second proposal was declined as well (Kravchenko 106).

The more traditional Little Russian gentry, unlike its new south Russian counterpart, had good reason to feel insulted. While the German barons and Polish nobles had obtained universities in "their" regional capitals-Dorpat and Vilnius, respectively-similar pretensions on the part of descendants of the Cossacks in the lands of the former Hetmanate had simply been ignored. Furthermore, the Little Russian gubernias were included in the Kharkiv educational district and thus subordinated to a city traditionally in opposition to the hetman's capital, wherever that capital happened to be at any particular time. The competition between Kharkiv and Kyiv for the role of university capital long continued to disturb not only gentry society but the government as well.

Not even a decade after the opening of Kharkiv University in 1814 , the new minister of public education, Count Andrii Rozumovs'kyi, a descendant of the last hetman of Little Russia, raised for discussion the issue of moving the university from Kharkiv to a city allegedly better suited for living. Almost half the members of the university's scholarly council then expressed themselves in favour of Kyiv (Kravchenko 107). The attempt yielded nothing. A similar fate awaited the last nineteenth century attempt to transfer the university from Kharkiv to Novhorod-Siverskyi, the former 
administrative capital of Little Russia. It was undertaken in the latter half of the 1820 s by the supervisor ("popechitel"') of the Kharkiv educational district, Aleksei Perovskii, yet another descendant of the last hetman of Little Russia. Finally, when none other than the imperial minister of education, Count Semen Uvarov, asserted that it was precisely Kyiv that should become the "educational centre of South Russia," it was too late to strip Kharkiv of that unofficial title (Kravchenko 114).

In connection with the reform of secular education, the choice between Kharkiv and Kyiv had a clearly delineated political subtext. Kharkiv became the centre of a university educational district because it was less associated with the regional historical privileges of the local gentry than any city in Little Russia or in the Polish borderlands ("kresy"). From the viewpoint of the centre, Kharkiv appeared to be a fulcrum for official policy intended to overcome the regional diversity of the southern and western borderlands of the empire and was expected to bring about their subsequent cultural and legal unification.

The Kharkiv educational district was made up of diverse regions of contemporary Russia and Ukraine, each with different traditions and ethnic composition: the Russian military borderland, the Cossack territories of the Sloboda region, Little Russia, the Don Cossack and Black Sea Cossack Hosts, the Crimea, New Russia, and even part of the Caucasus. It is striking that, as noted earlier, the sphere of administrative responsibility of the supervisor of the Kharkiv educational district at the moment of its delineation practically coincided with the territory subordinate to the military governor in the late eighteenth century. This was the borderland of Russian modernization.

Polish aspects also played a role in the history of the Kharkiv University project. The project of founding a university in Kharkiv won the support of the "Polish" party, headed by Prince Adam Czartoryski, who was influential at court. The motives guiding the Polish nobleman in his decision to support Kharkiv against Kyiv did not remain obscure to historians. According to James T. Flynn, Czartoryski expressed apprehension that the opening of a university in Kyiv might hamper his plans to establish a university in Vilnius (212).

Ivan Lysiak-Rudnyts'kyi noted that "Ukrainian national interest would have required favouring Kyiv," as that would have promoted the development of the Ukrainian national project, especially the cultural unification of Right- and Left-Bank Ukraine and the undermining of Polish gentry influence on the Right Bank. Lysiak-Rudnyts'kyi wrote,

Prince Czartoryski was right, as a Polish patriot, when he attempted to prevent the founding of a university in Kyiv. He was intent on including the three Right-Bank gubernias-Volyn, Podilia, and Kyiv-in the Vilnius 
educational district and thereby consolidating Polish cultural hegemony in those territories. And he managed to do so with the active assistance of the Ukrainian Karazin. (212)

Ironically, a new intellectual environment emerging around Kharkiv University did what the Little Russian traditionalists failed to do: it brought Sloboda Ukraine closer to Little Russia, if not politically then culturally. When the function of the chief marker of identity was gradually switching from religious and social to ethnocultural criteria-above all, linguistic - the residents of Slobidska Ukraine and neighbouring Little Russia began to share the name "Little Russians."

Kharkiv's entry into the Little Russian symbolic space was consolidated by its transformation in 1835 into the new administrative capital of the Little Russian Governorate General, which included the gubernias of Kharkiv, Poltava, and Chernihiv. And, although the city spent only about two decades in the role of capital city of Little Russia, this interval was sufficient to add Little Russian to its "Ukrainian" identity. When Hryhorii Kvitka [Osnov"ianenko], a prolific Sloboda-Ukrainian writer, historian, civil activist, and a patriot of his "small fatherland," attempted to reinterpret the "Ukrainian" regional identity in ethnic-cultural terms, he chose to write in the "Little Russian" language and not in the spoken local dialect.

In the second half of the nineteenth century and the beginning of the twentieth, Russian and foreign travellers (especially those from the north), judging by their travel notes, perceived Kharkiv as part of Little Russia. On one advertising leaflet Kharkiv is represented by the image of a girl dressed in a Little Russian folk costume. It seems like the "South Russian" imperial discourse paved a way for the regional identity to complement, not contradict, the Ukrainian nation-building on the reinvented Little Russian ethnic basis.

\section{FORMATION OF THE CITY}

By the second third of the nineteenth century Kharkiv was already regarded as a real city with all concomitant attributes. What contributed most to transforming Kharkiv's landscape was the founding of the university in 1805. Thanks to this, Kharkiv was enriched by its first public park and botanical garden, a boulevard, new places for rest and recreation, and new brick buildings.

The features of Kharkiv's urban landscape were aptly noted by the above-mentioned German scholar, Baron von Haxthausen, who visited the city in 1843. He left a detailed description of three components, Kharkiv's unique concentric circles, through which travellers passed on their way to 
the city centre. On the outskirts he encountered a "village with orchards and flower gardens" in the oldest part of Kharkiv; then came the "city of Catherine II," an imitation of a Muscovite suburb with long, straight streets, Russian artisans, taverns, and shops; finally, in the centre of Kharkiv was the "city of Nicholas I," a modern European city with straight streets, squares, and brick buildings, which, however, lacked vitality and movement (Haxthausen-Abbenburg 394).

As a city, Kharkiv experienced its second birth during the era of industrialization of the Russian Empire. It was precisely at this time that a cultural landscape of the city was formed, which has been preserved to the present day. Its architectural face was defined by its eclectic style, and in the early twentieth century by modern design. When Kharkiv's particular urban identity began to form, one of its features was the publication of numerous reference works, travel guides, and calendars that outlined the cultural space of the city and were aimed at the mass consumer. Arguably the most important representation of Kharkiv's urban identity was the fundamental two-volume history of the city written in the early twentieth century by two local historians, Dmytro Bahalii and Dmytro Miller, who were commissioned by the Kharkiv Municipal Duma.

During the new stage of Russian modernization, Kharkiv, along with Kyiv and Odesa, was transformed into a multinational, contemporary megalopolis. By the early twentieth century Kharkiv had a population of nearly 240,000: fewer people than in each of Kyiv and Odesa but more than in Lviv. The majority of Kharkivites were Russophones (63 percent), and Ukrainophones comprised nearly 26 percent (more than in Kyiv, or Lviv, or Odesa). In third place by a large margin were Jews, who comprised over six percent of the Kharkiv population, two times lower than the Jewish population in Kyiv and nearly five times lower than the Jewish population in Lviv or Odesa. Significant numbers of Jews were assimilated as the Russian society modernized. By the character of its cultural life at the beginning of the twentieth century, Kharkiv could be regarded as a Russian-Ukrainian city, where ethnic Ukrainians, although still a minority, were no longer isolated from the Russian population by legal or political barriers, as they had been two centuries earlier.

\section{FORMATION OF THE MYTH}

The rapid transformation of Kharkiv from a military free settlement/fortress into a contemporary city was accompanied by the formation of urban mythology. Its foundation was the idea of prosperity and progress. As stated earlier, it was introduced by Ornowski in 1705 in honour of the Kharkiv colonels, the Donets'-Zakharzhevs'kyis. It featured the symbolism of a 
blooming land created through the efforts of pious, loyal, and brave local leaders. The market trade contributed most to Kharkiv's growth. That is why the official coat-of-arms of the city during the second half of the eighteenth century featured a caduceus (the staff carried by Mercury, considered a symbol of trade) and a horn of plenty. The most profitable branch of the local economy - the free distillation and retail of "horilka," Ukrainian vodka-was not accorded such an honour.

The image of Kharkiv as a centre of education and science began to form in the second half of the eighteenth century and the beginning of the nineteenth. The philosopher Skovoroda called it "Zakharpolis," city of the sun, and he predicted a glorious future for it. However, the wandering philosopher refused to live in the city and contrasted it with the idyll of life in the countryside. In his writings, Karazin portrayed Kharkiv as a "Ukrainian Athens," a city where enlightened citizens, skilled artisans, and wealthy merchants lived amidst blessed natural surroundings, in a mild climate, where the arts and sciences burgeoned. Karazin's letters of "appeal," addressed to foreign professors, differed little from tourism brochures, and had a similar connection to reality.

The development of Kharkiv's urban mythology was facilitated by the founding of a university. According to Karazin, the Kharkiv University project was a response of the local community-above all the nobility, whose members were forever grateful to the powers that be for restoring some traditional, local privileges enjoyed by the "free settlements" - to the government's appeal to expand education in the country. Since its founding the university has defined Kharkiv as a "university town," and has become an immutable part of its "calling card."

Karazin's contemporary and countryman, Kvitka (Osnov'ianenko), also contributed to Kharkiv's modern mythology. In the following quotation the Ukrainian writer painted a vivid picture of the city:

Yes, the city of Kharkiv differs from many gubernial cities. Look at it in passing but with all attentiveness: beauty! The streets are even, clean, straight; public edifices are sumptuous, private buildings are nice, pleasant; the shops are filled with all kinds of merchandise and items in great quantities that are constantly being changed for newer, more sophisticated ones; no sooner than something appears in Petersburg, it has already been shipped to Kharkiv and sold. The street[s], theatre, shopping arcade, various art institutions . . . it lacks for nothing! ... It is a capital city, indeed (Hryhorii Kvitka 46).

Thanks to the university, the "capital city" rhetoric took root in local selfrepresentation long before Kharkiv had been proclaimed a capital of Soviet Ukraine. The local periodical, Ukrains'kyi zhurnal (Ukrainian Journal) solemnly assured readers that "of course, the city of Kharkiv, after our 
capital cities, can and must be regarded as the first in our homeland in terms of the striving for education on the part of the city's young people" (Losievskii 10).

Kharkiv left a similar impression on mid-nineteenth century travellers, including Johann George Kohl and Alexander Petzholdt (see Pettsol'dt); all reported that Kharkiv was one of the leading provincial cities of the Russian Empire, a flourishing city in the steppe, that was growing by leaps and bounds.

Kharkiv's modern European culture honed its ambitions to become a capital city. The Kharkiv myth resembled the Odesa myth, in which the paradigm of progress played a paramount role. In Russian and foreign correspondence of the time, Kharkiv and Odesa are mentioned as cities of the modern European type. However, unlike cosmopolitan Odesa with its many faces, Kharkiv kept a Ukrainian ethnic profile.

In the late nineteenth to early twentieth centuries, the concepts of "Ukraine" and "Little Russia" were radically reinterpreted and reformulated under the influence of modern nationalism. The first of these concepts came to signify modern national (ethnocultural) identity, while the second one remained part of early modern, Orthodox-Slavic "Russianness" ("rus'kost"'). The new "Ukraine," developing out of "Little Russia" and becoming distinct from it, came into conflict with the early modern Slavonic-Russian identity. As a result, a struggle was waged between Russian and Ukrainian national discourses for a symbolic control of Kharkiv.

On the symbolic map of Russian nationalism Kharkiv was part of the Orthodox-imperial space, marked by churches and other holy sites, rituals, mass demonstrations, and the names of the members of the imperial dynasty. With respect to these characteristics, Kharkiv belonged to the Russian centre, unlike Zhytomyr, for example, a city that was considered to be peripheral to Russia. This is one of the reasons that Orthodox Russian nationalists in Kharkiv were not as aggressive as those in, say, Odesa.

Imperial russification became one of the principal directions of the cultural policy of Kharkiv's local self-government, starting sometime around the end of the nineteenth century. The first large-scale renaming of Kharkiv's urban spaces was launched in 1894, with the names of distinguished figures of Russian culture (Ivan Turgenev, Aleksandr Pushkin, Mikhail Lermontov, Vasilii Zhukovskii, Nikolai Gogol' [Mykola Hohol', the author whose artistic legacy is claimed by both Russia and Ukraine], Gavriil Derzhavin, Nikolai Nekrasov, Nikolai Chernyshevskii, Vsevolod Garshin, and Petr Chaikovskii) and the names of Russian military leaders (Petr Bagration, Mikhail Skobelev, Aleksandr Suvorov, and Aleksandr Nevskii) (Kravchenko 204). The russification policy was distinctive in that two German-related names disappeared: German Street was renamed Pushkins'ka Street and the city park known as Bavaria was renamed Slov"ians'kyi Park. 
Kharkiv, along with Katerynoslav, belonged to the Ukrainian ethnocultural space. However, on the mental map of Ukrainian nationalism, Kharkiv appeared to exist on the outskirts compared to either Kyiv or Poltava. Furthermore, the Russian-speaking metropolis contrasted markedly with the Ukrainian-speaking countryside. Thus, from the outset Kharkiv often presented a negative image in the Ukrainian national discourse, which was closely linked to the conservative, anti-urban tradition that can be traced to the works of Iakiv Shchoholiv and Serhii Vasyl'kivs'kyi. Kharkiv rendered an image of a city distorted by modernity, something that was especially tangible against the background of the patriarchal, rural landscape.

Russian cultural influences could also be perceived as part of the alien, hostile modernity. For example, when asked why Kharkiv never figured in his touring schedule, the Ukrainian composer, pianist, conductor, and ethnomusicologist Mykola Lysenko replied:

It was with a great pain in my heart that I did not see, did not feel the Ukrainian people in Kharkiv, did not see a Ukrainian community; there, everything is smeared with, trampled by the Muscovite spirit, Muscovite tastes. Indeed, everything is not ours, everything is foreign, not our own. (Laia 51)

Lysenko's contemporary, the prominent civic leader, patron of Ukrainian culture, and publisher, Ievhen Chykalenko, considered Kharkiv to be the most "Muscovitized" of all Ukrainian cities.

The Ukrainian intelligentsia launched a struggle for the cultural space of Kharkiv under the banner of Ukraine's national poet Taras Shevchenko. A street and one of the first schools in the city were named after him, but the city fathers of imperial Kharkiv did not see fit to erect a monument to the poet. The very first monument to Shevchenko in Ukraine, erected on the grounds of the Alchevs'kyis' private estate in 1899, was dismantled at the demand of the police, and the 1911 decision of the Municipal Duma to erect a column featuring the poet's image was never implemented. In 1904, when members of a Ukrainian youth organization attempted to destroy a monument to the Russian poet Pushkin located in the city centre (Masliichuk 357), their actions were motivated by the official ban on honouring Shevchenko in Kharkiv. The monument to Gogol', which was erected opposite the Pushkin statue five years later, did not elicit such strong emotions.

A positive image of Ukrainian Kharkiv-based on an earlier intellectual tradition that may be traced from Ornowski through Skovoroda, Karazin, and Kvitka, all the way to Bahalii-is the image of a cultural capital, a city that became the centre of modern Ukrainian poetry, prose, and literary criticism. Moreover, the "Ukrainian" and "Slobids'ka Ukraine" terminology 
of Kharkiv in the eighteenth and the beginning of the nineteenth centuries, which initially had mostly regional, geographic significance, was restored to the public and cultural spaces of the city a hundred years later, but with a national look. Urban phenomena and events underwent "Ukrainization." The phenomenon of budding Ukrainian culture thereby acquired historical legitimacy, and Kharkiv was included in the Ukrainian national discourse, not as a mere neighbourhood but with the prestigious status of capital city.

The struggle for Kharkiv waged by Ukrainian and Russian national discourses transformed into a struggle for local historical and cultural heritage. Its most vivid expression was the unveiling of a monument to Karazin in the city (Kravchenko 206-07). One can find everything in the works of this enlightener from Slobids'ka Ukraine: free thinking and servilism, Westernism and Pan-Slavism, traditionalism and reformation. However, the contradictory nature of Karazin's views opened the way for differing interpretations of his persona.

Thanks to the efforts of Kharkiv's liberal intelligentsia, Karazin emerged as a prominent civic figure, who championed the need for democratic reform and education in the Russian Empire. The inscription on the pedestal of the monument to Karazin, erected in Kharkiv in 1907, states: "I have been blessed one hundredfold if circumstance has allowed me to do the smallest good for my Ukraine, whose benefits are so closely bound up with the benefits of gigantic Russia." Karazin used the word "Ukraine" in its territorial, regional meaning. However, at the beginning of the twentieth century, it acquired a new, national sense. After all, Bahalii used the dual meaning of this term successfully in his scholarly works in order to bypass the censors.

The members of the Black Hundreds in Kharkiv-Russian nationalistslost the ideological struggle for Karazin to their political opponents. In their interpretation, Karazin was cast in the unattractive role of adventurer, promoter of hare-brained schemes, and informer, who was unscrupulous about the ways in which he satisfied his vanity. For that reason, the Black Hundreds opposed the idea of a monument to Karazin. Of course, such an interpretation had no hope of garnering broad public support, considering the reputation of the Black Hundreds movement, which was tarnished by anti-Jewish pogroms and by its members' direct links with the odious autocratic regime.

However, the attempts at national reinterpretation of Kharkiv's public space at the turn of the nineteenth century did not leave a perceptible trace on the landscape of the city. Describing Kharkiv in the year 1916, the Russian journalist Petr Pil'skii noted only that the city lacked its own style and presented a mixed Russian-Ukrainian population: 
It is Little Russian but also Great Russian, and the Great Russians are trying with all their might to say how real and sincere the khokhols are, while the Little Russians are affixing the suffix 'ov' to their surnames, and they are not even opposed to becoming Great Russians, although their songs scorn the Muscovite, and they are creating a hymn to Ukraine alone and only in the exclusively Ukrainian style .... There are various cities in Russia: clever ones and stupid ones, chaste ones and dissolute ones, beauties and monsters, old ones and infants. But in Russia there is only one ill-defined city. That city is Kharkiv.

If one acknowledges the accuracy of these words, one can understand why the regional dimension of Kharkiv's identity successfully withstood competition with the national one.

\section{THE STRUGGLE FOR THE REGION}

With the onset of World War I, which led to the collapse of the Russian Empire, Kharkiv once again ended up in the role of border city, while Slobids'ka Ukraine was transformed into a military frontier for the second time in its history. The new political configuration of eastern Europe at the dawn of the twentieth century emerged as a result of the long-standing conflict among the regional, national, and religious discourses, each of which projected different interpretations of "Russia" and "Ukraine" and the kind of relations that should exist between them and their respective neighbours. After all, this was a conflict between modernity and traditionalism, which ended in yet another compromise.

The main bone of contention in the relations between democratic Russia and democratic Ukraine after the fall of the autocracy was the question of national and state affiliations of Slobids'ka Ukraine and "Southern Russia." In the understanding of the Provisional Government, Ukraine was limited to the territory of historical Little Russia. From the standpoint of the Central Rada, the revolutionary Ukrainian parliament, all the territories in which the populations spoke the Ukrainian language were to be considered Ukraine. Depending on the results of negotiations and the balance of power, Kharkiv could have ended up on one side or the other of the Ukrainian-Russian border. In this case, however, the national principle of the political definition encountered a serious competitor.

The national interpretation of "Ukraine" challenged the concept of "Southern Russia," which was based predominantly on economic principles and encompassed Kharkiv, Katerynoslav, Kherson, and Tavria gubernias, all of which were located within the sphere of the administrative influence of the Congress of Mining Industrialists of Southern Russia, with its centre in Kharkiv. It is no accident that the long-standing head of this organization, the 
Kharkiv industrialist Nikolai von Ditmar, was an active promoter of the idea of Southern Russia, and his associates included not only the members of the Kyiv civic organization Union of Southern Russians, and the professors of the local Polytechnical Institute, but also communists.

It is generally accepted that the Bolsheviks were not of one mind where Ukraine was concerned: some members of the party leadership recognized the principle of national self-determination and leaned toward compromise on the Ukrainian question, while others prioritized the territorial-political principle of reformatting the former empire over the national principle. Kharkiv, the largest city on the Ukrainian-Russian border, became a kind of testing ground for these groups in 1917 when the city was proclaimed the capital city of Soviet Ukraine, and in February 1918 when the city was proclaimed the capital of the Donetsk-Kryvyi Rih Republic. In the first case, "Ukrainian" terminology became dominant, while "southern" terminology predominated in the latter case. The national interpretation of "Ukraine" finally vanquished the regional interpretation in late 1919, when Kharkiv was once again proclaimed the capital of Soviet Ukraine. However, the second, "southern," component of the "Ukrainian" project never disappeared from Soviet intellectual discourse.

\section{CAPITAL OF THE UKRAINIAN PROLETARIAT}

Kharkiv's selection as the capital city of Soviet Ukraine was determined above all by its military and strategic importance as a transportation route, and by its proximity to both Moscow and the Donetsk-Kryvyi Rih Basin. In fact, Kharkiv was restored to its role as a fort on the steppe borderland when it became the headquarters of the Soviet armies that were advancing on the South. Subsequently, plans were drafted to commemorate this role of Kharkiv in the Civil War in the form of a gigantic diorama depicting the storming of Perekop in 1920 by Soviet troops commanded by Mikhail Frunze. However, in late 1919-early 1920 the strategic situation in the southern and western directions remained nebulous: the Crimea was still controlled by White Guard forces, the southeastern territories were under the control of Makhno's troops, and the western lands were controlled by Ukrainian and Polish troops.

Political factors, too, played a role in Kharkiv's ascendance. Although the idea of establishing the Donetsk-Kryvyi Rih Republic was ultimately scrapped, quite a few stalwart proponents of this project, headed by the revolutionary Soviet statesman and party activist Fedor Sergeev (aka "Artem") until his death in 1921, remained in the party leadership. They would hardly have agreed readily to transfer the capital to Kyiv, which by that time had managed to become a prominent centre of Ukrainian 
nationalism and still bore the mark of the Central Rada and Hetmanate governments. Meanwhile, Kharkiv played the role of an alternate Kyiv and a political centre under Moscow's control-not for the first time in the history of this city. The early 1920s marked the beginning of Kharkiv's sudden but short-lived career as the experimental capital of Soviet Ukraine.

The city began to expand feverishly, and its population grew by geometric progression. By the early 1930s, Kharkiv, with its 521,000 residents, was not far behind Kyiv, which continued to be the most populous place in Ukraine. Kharkiv's ethnosocial structure also underwent marked changes. Ethnic Ukrainians were now in the majority (38.6 percent in 1926), while the number of ethnic Russians dropped to 37.2 percent (that same year). As well, the proportion of Jews also grew appreciably (to nearly 20 percent). It is worthwhile mentioning that the changes in the relationship between Ukrainians and Russians were caused primarily by the changes in national self-identification.

The cultural space of the Ukrainian "proletarian" capital experienced cardinal changes. By 1919 Kharkiv had already passed through the first wave of Sovietization, when some central streets and squares in the city received new names. For example, Sums'ka Street was renamed Karl Libknekht Street, Katerynoslavs'ka Street became Sverdlov Street, Pavlivs'ka Square was renamed Roza Liuksemburg Square, and Mykolaiv Street became known as Tevelev Street. This list was later expanded to include the names of Soviet military leaders, French revolutionaries, Red trade unions, and the like. After his death, Artem, the former head of the Donetsk-Kryvyi Rih Republic, became one of the most popular symbols of Kharkiv: a street, a museum, a communist university, and a library club were all named in his honour.

Kharkiv, the capital city, was transformed into a laboratory of architectural innovations, a symbol of functionalism and constructivism, and the embodiment of the communist utopia of the industrial age and new civic life. In addition to a new centre, plans were drafted for the construction of a new socialist city filled with communal buildings and workers' settlements. The geometric form of the new streets and avenues, buildings constructed of concrete, glass, and iron, the blend of daily life with industry, were some of the features of the new capital city that had taken on the role of an unknown, newly discovered industrial giant, whose hands were the streets of Kharkiv exhaling the smoke of factories.

The idea of modernization in the mythology of the new Kharkiv was linked with the Ukrainian national idea. The latter was called to mind in particular by symbols borrowed from the arsenal of local tradition that was reinterpreted in the national spirit at the turn of the nineteenth century, especially the names of Skovoroda, Kvitka, Vasyl'kivs'kyi, and Oleksandr Potebnia. The ancient name of the region, Slobids'ka Ukraine, was also used 
in the public discourse. But the most vivid symbol of Kharkiv's "Ukrainianness" was the monument to Shevchenko, which, ironically, appeared in the city at the very time that the new capital of Ukraine had once again been turned into a regional one. Moreover, it was not Pushkin whom Shevchenko had supplanted but Karazin, who was not even included in the new pantheon of progressive Ukrainian figures, and for some time disappeared from the urban symbolic space along with the old university.

Even though the historic centre of Kharkiv managed to avoid destruction, it lost its former social and cultural role. A new downtown core constructed on the northern outskirts of the city was supposed to symbolize the bright future of humanity: a huge, open space, advertised as the largest in Europe, was surrounded by a new-type of government structures and residential buildings. This space, called Dzerzhinskii Square, was a place of public meetings, parades, and the people's open-air revelries. This was where the "Derzhprom" ("State Industry") building, an edifice that became the symbol of Soviet modernization, was constructed in the mid-1920s; it was the first Soviet skyscraper, and its "American" look was hallowed by the writer Theodore Dreiser (220).

The new, communist, capital city of Ukraine sparked ambiguous feelings in the Ukrainian intelligentsia. The older generation of cultural figures did not accept Kharkiv in this role. Entries recorded under 1925 in the diary of the Ukrainian literary historian and critic Serhii Iefremov hark back to Kharkiv's negative image in the Ukrainian cultural milieu of the prerevolutionary period: "A city of liars and speculators, swollen reputations, arrogance and ignorance, idlers, and prattlers. Every city has its own soul, so to speak; only in Kharkiv is it not in evidence. A rather bad copy of Asiatic Moscow with limitless pretensions" (262). While Iefremov could not discern the soul of Kharkiv, the Soviet Ukrainian poet Pavlo Tychyna was unable to detect the features of Kharkiv's face ("dark as night"), and his colleague, the writer Mykola Khvyl'ovyi, doubted that the city had preserved the memory of its own history (131-32).

However, the youthful age of the new capital city, its "unfettered" openness to innovations, its orientation toward the future, and its elemental "Sturm und Drang," which was contrasted with Kyiv's "burgher" orderliness, foresight, and refinement, attracted the rising generation of Ukrainian intellectuals, who set out to "conquer" the city with a communist manifesto in one pocket and a portrait of Shevchenko in the other. This generation of the "Executed Renaissance" managed to inscribe Kharkiv in the contemporary national narrative, overcoming the conservative, anti-urban traditions of the Ukrainian culture. Khvyl'ovyi's manifesto, "Ukraina chy Malorosiia" ("Ukraine or Little Russia"), written in Kharkiv, demonstrated the Ukrainian national capacity for intellectual modernization. 
Ukrainianness and modernity were linked for a certain period of time in Kharkiv, but once again began to disengage when Kyiv was restored as the capital of Ukraine in 1934. Among the reasons for the Soviet leadership's decision, the Canadian scholar Serhiy Yekelchyk names the international situation, the rejection of the policy of Ukrainization, and the steadily increasing scale of repressions in Ukraine.

In the confrontation between the two cities, there is no question that Kyiv's latest victory over Kharkiv may be interpreted in the context of the Stalinist leadership's policy of the "Great Retreat" and the partial return from communist experimentation to traditionalism. During Ukraine's gradual "Little Russianizing" in the USSR, which in turn was becoming increasingly more similar to the Russian Empire, Kyiv once again ended up in the role of Ukraine's "natural centre," whereas Kharkiv, quite the opposite, was gradually shunted to the margins. In the postwar years the attempt to secure the official title of "the second capital" for Kharkiv ended in failure.

Nevertheless, Kharkiv, along with Moscow and Leningrad, became part of the principal "group of three" in the new hierarchy of Soviet cities according to the dismal criterion of the restriction of civic rights and freedoms. It was in these three cities that the passport system in the USSR, legislated in late 1932, was widely introduced. They were the ones that topped the list of so-called "forbidden" Soviet cities, where "politically undesirable elements" could not obtain a permanent residence permit. These three cities were home to the largest Soviet military-industrial complex. Finally, the notorious show trials of the late 1920s and early 1930s, whose infamy was known throughout the world, took place in these very cities. At most, Kharkiv differed from Moscow and Leningrad by its specific local features: the Ukrainian Famine-Genocide, known as the Holodomor, and the mass shootings of Polish officers.

\section{THE SOVIET STANDARD}

After the loss of its capital city status Kharkiv began a rapid descent into provincialization, and it became part of the unified Soviet cultural space with its standard details, architecture, and toponymy. It remained a megalopolis oriented culturally toward Moscow and Leningrad, with its numerous institutes of higher education, its defense industry, and its all-Union industries. From time to time Kharkiv's southern geographic orientation visà-vis Moscow made its presence known through some of its enterprises, its scientific research institutes, the main railway line, and experiments in decentralization. Paradoxically, the city's entry into the Soviet Russian cultural space took place alongside Kharkiv's affirmation within the symbolic Ukrainian space. At this time the city's "southern" geographic 
orientation vis-à-vis Moscow began to be supplemented by its "northeastern" location with respect to Kyiv (Kravchenko 243). As it turned out, the virtually undetectable administrative border between the two Soviet republics was still based on the symbolic ethnocultural markers of the Ukrainian-Russian borderland (Chizhikova 38).

The periodic changes in Kharkiv's cultural landscape during the Soviet era took place in conformity with (i) the "fluctuations in party policies": the advent of the Stalinist "Empire style" with its gloomy military-industrial, communist symbols and names of Stalinist leaders; (ii) de-Stalinization in the form of "Leninization" based on the historical mythology of the Great October Socialist Revolution, together with the low-cost, concrete-panelled, or brick three- to five-storied apartment buildings known as "khrushchevki"; and (iii) cautious Brezhnevian re-Stalinization founded on the mythologized memory of the Great Patriotic War along with new "bedroom communities" and a subway system. These three sources of the city's recent past are still the important three components of its present life, similar to Haxthausen's descriptions of "three cities in one."

However, each political pirouette of the communist leadership forced it to dip into the symbolic capital of the prerevolutionary era; in fact, from two cultural eras: the Ukrainian Cossack and the imperial. As a result, Kharkiv's pre-Soviet past was gradually resurrected. For example, in the late 1940s to early 1950s the "reverse" renaming of some streets in Kharkiv took place: Karl Libknekht Street was replaced by Sums'ka Street, Klara Tsetkin Street was renamed Rymars'ka, and Vil'na Akademiia Street became known as Universytets'ka. Then it was Karazin's turn: he was restored to prominence and recognized as a "progressive" public figure, who had played the role of a "Ukrainian Lomonosov."

The return to "Leninist principles of the nationality policy" was accompanied by the partial rehabilitation of some Ukrainian cultural figures and representatives of the age of the "Executed Renaissance," and by topics related to regional history, particularly that of Slobids'ka Ukraine. In addition, historical narratives and their authors, the historian Bahalii for one, returned to public attention. In contrast, the subsequent Brezhnev era drew closer to the Russian imperial legacy and was marked by deUkrainization and the growing influence of Russian nationalism, cloaked in the official rhetoric of the "friendship of peoples." Later, the ideological failure of the Soviet internationalist project and a turn back to the national became increasingly more obvious. 


\section{CONCLUSIONS}

Kharkiv's borderland status appeared to be one of the city's most stable components, emerging in public life in times of geopolitical cataclysms and becoming less visible in times of internal stability. After the collapse of the Soviet Union in 1991, Kharkiv was turned once again into a borderland city, while the Ukrainian-Russian borderland became fragmented both politically and symbolically. The Ukrainian-Russian border affected the image and perception of Kharkiv as a borderland city, and the public representations of Kharkiv today are often accompanied by traditional markers of the former military frontier, such as the "Muravs'kyi Route," the "Wild Fields," and the "Steppe."

The representation of Kharkiv in the Ukrainian national narrative remains traditionally contradictory. In order to single out its discrete features, one must turn to the metaphor of the "Executed Renaissance." In emphasizing the word "Renaissance," we are actualizing the historical mythology of Kharkiv University, Karazin, local cultural figures of the nineteenth century, and, obviously, the process of Ukrainization during the period of National Communism; an emphasis on "Executed" recalls the Communist Revolution of 1917, political repressions, and the Holodomor of 1932-33. From the "cradle of the Ukrainian Renaissance" Kharkiv can be easily transformed into the "capital of despair," "sin city," and the victim of forcible, brutal Russification.

The vision of Kharkiv in the Russian nationalist discourse is a mirror image of the Ukrainian discourse. On the mental map of contemporary Russian nationalism, Kharkiv is still located in the imperial space, and recently has been associated with the historical regions of Little Russia or Novorossiia. In the Russian nationalist discourse, Kharkiv is a border fortress in the Wild Fields, cut off from its Russian body, and just like the Brest fortress, it is waging a heroic, unequal struggle against an aggressive and treacherous enemy-in this case, Ukrainian nationalism, behind which stands the hypocritical, treacherous West (Minakov).

The reaction to the establishment of a "strict" Ukrainian-Russian border was diametrically opposite in Ukrainian and Russian discourses. Ukraine sought to transform this border into the impregnable "European wall," underscoring the ethnocultural and civilizational differences between Ukrainians and Russians, substantiating the antecedence of Ukrainian colonization of Slobids'ka Ukraine over Russian, and emphasizing the Russian centre's policy of Russification in the city and the region as a whole. Russia aimed to minimize the influence of the "strict" border by using imperial terminology and symbols and emphasizing the commonality of historical and cultural features cultivated by the Orthodox Church and the Russian Empire. 
It is worth noting that so far, all attempts to rethink the past of Kharkiv and the Kharkiv region have been conducted with rhetoric inherited from the old imperial discourses, both Soviet and pre-Soviet. Those trying to reinvent and establish new regional and urban identities usually operate with the same arsenal of symbols, images, and myths, but charge them with different meanings. The post-Soviet generation has not produced new discourses of collective identity that would be able to replace the old ones. The symbolic space of Ukrainian identity remains highly heterogeneous at all points, and even its near future looks murky. Contradictory images of Kharkiv reflect its elusive and ambiguous identity, which annoys the national narrative but seems to be perfectly "normal" for the borderland. 


\section{Works Cited}

Amar, Tarik Cyril. The Paradox of Ukrainian Lviv: A Borderland City between Stalinists, Nazis, and Nationalists. Cornell UP, 2015.

Arnold, Dana, editor. The Metropolis and Its Image: Constructing Identities for London, 1750-1950. Blackwell, 1999.

Augusteijn, Joost, and H. J. Storm, editors. Nation and Region: Nation-Building, Regional Identities and Separatism in Nineteenth-Century Europe. Palgrave Macmillan, 2012.

Bagalei, Dmitrii (Dmytro Bahalii), and Dmitrii Miller (Dmytro Miller). Istoriia goroda Khar'kova za 250 let ego sushchestvovaniia (s 1655 po 1905 god). Reprinted edition, Kharkiv City Press, 1993. 2 vols.

Bahalii, Dmytro. Istoriia Slobids'koi Ukrainy. Vyshcha shkola, 1993.

Belinskii, Vissarion. Polnoe sobranie sochinenii. Vol. 8: Stat'i i retsenzii, 1843-45. Akademiia Nauk SSSR, 1955.

Berger, Stefan, and Aleksey Miller. "Nation-Building and Regional Integration, c.1800-1914: The Role of Empires." European Review of History, vol. 15, no. 3, 2008, pp. 317-30. DOI: 10.1080/13507480802082649

Bilenky, Serhiy. Imperial Urbanism in the Borderlands: Kyiv, 1800-1905. Toronto UP, 2018.

Breyfogle, Nicholas B., et al., editors. Peopling the Russian Periphery: Borderland Colonization in Eurasian History. Routledge, 2007.

Chizhikova, Liudmila. Russko-ukrainskoe pogranich'e: Istoriia i sud'by traditsionnobytovoi kul'tury (XIX-XX veka). Nauka, 1988.

Czaplicka, John, et al., editors. Cities after the Fall of Communism: Reshaping Cultural Landscapes and European Identity. Woodrow Wilson Center Press with John Hopkins UP, 2009.

Czaplicka, John, editor. Lviv: A City in the Crosscurrents of Culture. Harvard UP, 2000.

Dolengo, Mykhailo. "Kyiv ta Kharkiv-literaturni vzaiemovidnoshennia." Chervonyi shliakh, nos. 6-7, 1923, pp. 151-57.

Dreiser, Theodore. Russian Diary. Pennsylvania UP, 1996.

Eliseeva, Ol'ga I. Geopoliticheskie proekty G. A. Potemkina. RAN Press, 2000.

Emden, Christian, et al. Imagining the City. Vol. 1, Peter Lang, 2006.

Flynn, James T. "V. N. Karazin, the Gentry and Kharkov University." Slavic Review, vol. 28, no. 2, 1969, pp. 209-20.

Hamm, Michael F. Kiev: A Portrait, 1800-1917. Princeton UP, 1993.

Haxthausen-Abbenburg, August Franz Ludwig Maria von. The Russian Empire, Its People, Institutions, and Resources. Vol. 1, Chapman and Hall, 1856.

Herlihy, Patricia. Odessa Recollected: The Port and the People. Academic Studies Press, 2018.

Hrytsenko, Oleksandr. Pam"iat' mistsevoho vyrobnytstva: Transformatsiia symvolichnoho prostoru ta istorychnoi pam"iati v malykh mistakh Ukrainy. K.I.C. Press, 2014.

Iarmysh, Oleksandr, et al., editors. Istoriia mista Kharkova XX stolittia. Folio, 2004.

Iavornitskii, Dmitrii Ivanovich (Dmytro Iavornyts'kyi). Istoriia goroda Ekaterinoslava. Promin', 1989.

Iefremov, Serhii. Shchodennyky, 1923-1929. ZAT “Rada,” 1997. 
Istoriia Rusov ili Maloi Rossii. Chteniia v Obshchestve istorii i drevnostei rossiiskikh, 1846.

Janowski, Ludwik. Uniwersytet Charkowski w pozatkach swego istnienia (1805-1820). Akademia Umiejetnosci, 1911.

Khvyl'ovyi, Mykola. Tvory, Naukova Dumka, 1995.

Kohl, Johann G. Russia: St. Petersburg, Moscow, Kharkoff, Riga, Odessa, the German Provinces on the Baltic, the Steppes, the Crimea, and the Interior of the Empire. Chapman and Hall, 1842.

Kravchenko, Vladimir. Khar'kov/Kharkiv: Stolitsa pogranich'ia. European Humanities University P, 2010.

Kvitka, Hryhorii. Khar'kov i uezdnye goroda. 2005.

[Kvitka, Illia]. Zapiski o slobodskikh polkakh s nachala ikh poseleniia do $1766 \mathrm{~g}$. Khar'kovskaia universitetskaia tipografiia, 1812.

L-aia, T. V. "Vospominaniia o N. V. Lysenko odnoi iz ego uchenits po Kievskomu institute blagorodnykh devits." Vestnik Khar'kovskogo istoriko-filologicheskogo obshchestva, 13, 1913, pp. 50-55.

LeDonne, J. P. The Grand Strategy of the Russian Empire, 1650-1831. Oxford UP, 2004.

Losievskii, Igor'. Russkaia lira s Ukrainy: Russkie pisateli Ukrainy pervoi chetverti XIX veka. Oko Press, 1993.

Low, Setha M. "The Anthropology of Cities: Imagining and Theorizing the City." Annual Review of Anthropology, vol. 25, 1996, pp. 383-409. DOI: 10.1146/annurev.anthro.25.1.383

Lysiak-Rudnyts'kyi, Ivan. Istorychni ese. Vol. 1, Osnovy, 1994.

Masliichuk, Volodymyr. Provintsiia na perekhresti kul'tur: Doslidzhennia z istorii Slobids'koi Ukrainy XVII-XIX st. Kharkivs'kyi pryvatnyi muzei mis'koi sadyby, 2007.

Minakov, Stanislav. "Khar'kov: priznaki zhizni." Znamia, no. 5, 2001, http://znamlit.ru/publication.php?id=1437. Accessed 31 Mar. 2020.

---. "Novaia pokhodnaia pesnia slobodskikh polkov." Kharkiv"iany: Poema pro misto $v$ tsytatakh poetychnykh tvoriv. Slobozhanshchyna, 2007, pp. 363-64.

Nilsson, Lars, editor. Capital Cities: Images and Realities in the Historical Development of European Capital Cities. Stads-Och Kommunhistoriska Institutet, 2000.

Núñez, Xosé M. "The Region As Essence of the Fatherland: Regionalist Variants of Spanish Nationalism (1840-1936).” European History Quarterly, vol. 31, no. 4, 2001, pp. 483-518. DOI: 10.1177/026569140103100401

Paasi, Anssi. "The Resurgence of the 'Region' and 'Regional Identity': Theoretical Perspectives and Empirical Observations on Regional Dynamics in Europe." Review of International Studies, vol. 35, no. S1, 2009, pp. 121-46. DOI: 10.1017/S0260210509008456

Pettsol'dt, Aleksandr (Alexander Petzholdt). "Kratkii otchet ob uchenom puteshestvii v iuzhnye gubernii Evropeiskoi Rossii." Zhurnal Ministerstva narodnogo prosveshcheniia, no. 3, 1856, pp. 47-66.

Pil'skii, Petr. "Khar'kov" [(1916]. Sloboda, 11, 1992.

Posokhov, Serhii Ivanovych. Obrazy universytetiv Rosiis'koi imperii druhoi polovyny XIX-pochatku XX st. v publitsystytsi ta istoriohrafii. KhNU imeni V. N. Karazina, 2006. 
Richardson, Tanya. Kaleidoscopic Odessa: History and Place in Contemporary Ukraine. Toronto UP, 2008.

Schlögel, Karl. Ukraine: A Nation on the Borderland. Translated by Gerrit Jackson, Reaktion Books, 2018.

Shevel'ov, Iurii. Porohy i Zaporizhzhia: Literatura, Mystetstvo, Ideolohiia. Vol. 1, Folio Press, 1998.

Sklokin, Volodymyr. Rosiis'ka imperiia i Slobids'ka Ukraina u druhii polovyni XVIII st.: prosvichenyi absoliutyzm, impers'ka intehratsiia, lokal'ne suspil'stvo. Vydavnytstvo UKU, 2019.

Sylvester, Roshana. Tales of Old Odessa: Crime and Civility in a City of Thieves. DeKalb, 2005.

Westwood, Sallie, and John Williams. Imagining Cities: Scripts, Signs, Memory. Routledge, 1997.

Yekelchyk, Serhy. "The Making of a 'Proletarian Capital': Patterns of Stalinist Social Policy in Kiev in the Mid-1930s." Europe-Asia Studies, vol. 50, no. 7, 1998, pp. 1229-44. DOI: 10.1080/09668139808412592

Zaharchenko, Tanya. "The Fifth Kharkiv." New Eastern Europe, nos. 3-4, 2015, pp. 30 38.

---. Where Currents Meet: Frontiers in Post-Soviet Fiction of Kharkiv, Ukraine. Central European UP, 2016.

Zorin, Andrei. Kormia dvuglavogo orla... Russkaia literatura i gosudarstvennaia ideologiia $v$ poslednei treti XVIII-pervoi treti XIX veka. Novoe literaturnoe obozrenie, 2001. 